\title{
СТЕПЕНОТ НА ГЛОБАЛИЗИРАНОСТ НА ЗЕМЈИТЕ ОД ЗАПАДЕН БАЛКАН
}

\section{Крайка сооржина}

Глобализачијайа нема еянакво влијание врз земјитие, өејсиивува различно во земјийе со различен сииейен на йолитиччк, економски и йехнолошки развој. Нејзинайа нееянаква расйреgелба йо реіиони, земји или заеяничи йойвряува яека йаа е сложен и ялабок асимейричен йрочес. Тоа іо йойвроија бројни йеории $и$ gебайи кои само ја објаснуваа и яефинираа йојавайа, но малку внимание йосвейија на комйлексносйа на ілобализачијайа и мерење на нејзиниой ойсеі. Со йомош на емйирискийе йоказайели и иноикайори може яа се измерай разликийе мет́у начионалнойо и инитерначионалнойо во различни оомени. На йој начин се овозможува gа се вияи яо колкав сйейен земјийе се ілобализирани, ояносно се соілеоува силнойо влијание на ілобализачиските йрочеси врз севкуйнайа сосйојба во ойшйестиват̄а. Зайоа йоїолем број земји се обияуваай qа іи искорисйай

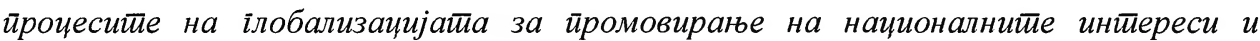
йоgобрување на својатиа йозиција во метунароянийе ооноси. Оййука анализайа на иняексийе на ілобализираносй ке ни йомоіне gа осознаеме со кои комйоненйи на начионална моќ земјийе ооминираай на реіионалнайа и ілобалнайа сцена

Клучни зборови: ИНДЕКСИ НА ГЛОБАЛИЗИРАНОСТ, ВАРИЈАБЛИ, РЕЈТИНГ, ЗАПАДЕН БАЛКАН

\section{Вовеg}

Дискурсот на глобализацијата се базира на теории што даваат одредени објаснувања и дефинирања на појавата, но комплексноста се јавува кога треба глобализацијата да се сведе на емпириски показатели и индикатори. Прв пат, во списанието „Форин полиси“ (Foreign Policy) се појави наслов „Мерење на ілобализачијайа“ каде што се потенцираше дека „сите говорат за глобализацијата, но никој не се обидел да го измери нејзиниот опсег, секако не досега“" (Foreign Policy, 2001:56-65). Па оттука, во спомнатиов текст за показатели се земени предвид индикатори што придонесуваат и ја поттикнуваат интеграцијата, а тие се: прекуграничните лични контакти, меѓународните телефонски јавувања, меѓународната поштенска размена, бројот на корисници на World Wide Web, странските директни инвестиции, трговската размена, учеството во меѓународни мировни мисии и др. Всушност, со емпириските индикатори се прави обид да се даде „слика“ за разликите меѓу националното и интернационалното, а кои, всушност, претставуваат и главни сили што го прикажуваат степенот на глобализираност. Притоа, не постојат јасно зацртани правила или шеми според кои треба да се раководат земјите, напротив, станува 
збор за „манипулација со варијаблите“, така што еден индикатор за степенот на глобализираност важи за една земја, но не и за друга. Оттука, поради комплексноста на глобализацијата, во многу случаи се даваат погрешни дијагнози, затоа што таа не е поединечен процес, туку збир на процеси што дејствуваат истовремено и нерамномерно на неколку нивоа и во различни димензии (Steger, 2005:35). Тоа имплицира потреба од подетално идентификување, истражување и процени на процесите на глобализацијата во секој домен, а притоа да не се излезе од зацртаната рамка на нејзино функционирање и остварувањата. Но, да видиме кој и колку е глобализиран, на чија штета или за која корист, кој, кого глобализира и под кои услови?

\section{Како се мери ойсеїой на ілобализацијайа?}

Постојат неколку реномирани индекси на глобализираност, кои даваат слика за рејтингот на земјите и движењата во овој сегмент, тие индекси се изработени од Ценйарой за йроучување на ілобализачијайа и реіионализачијайа (ЦПГР) (CSGR - Center for Study of Globalization and Regionalization), A.T. Керни и швајцарскиот Инсииитиуй за економија $К О Ф$ (Konjunkturforschungsstelle - KOF). Нивните резултати за глобализираноста на земјите се базираат на индикатори кои се категоризирани во три групи и тоа: економски, политички и социјални аспекти на глобализацијата. Но, некои од горепосочените индекси имаат одредени недостатоци што се однесуваат на начинот на селектирање на варијаблите кои ја „искривуваат“ сликата и го прикажуваат необјективно степенот на глобализираност на земјите.

Ценйароти за йроучување на ілобализачија и реіионализачија (ЦПГР) е основан во 1997 година и е најголем академски центар во Европа што се занимава со оваа проблематика. Истражувањата на ЦПГР се фокусирани кон политичката економија, особено на односот меѓу глобалните и регионалните аспекти и за дебати поврзани за современата политика (Lockwood \& Redoano, 2006). Меѓутоа, според ЦПГР, најекспонирани се земјите од Западна Европа, кои доминираат според степенот на глобализираност во изминатите три децении. Огромен недостаток е тоа што не постојат релевантни податоци за глобализираноста на земјите од Западен Балкан.

Индексот на глобализираност според $A$. T. Керни (која е водечка глобална компанија за менаџмент и консалтинг-услуги во повеке од 40 земји во светот и која соработува со повеќе од 2/3 од најголемите компании во светот рангирани според Fortune Global 500 ) опфаќа 62 земји (во 2001 година се опфатени 50 земји), кои остваруваат 96\% од светскиот БДП и сочинуваат 85\% од светската популација. Индексот е базиран на 12 варијабли групирани во четири категории, и тоа: економскайа инйеірираносй (слободна трговија и странски директни инвестиции), лични конйакйи (меѓународни патувања и туризам, мегуународен телефонски сообраќај, трансфер на луѓе и др.), च̄ехнолошка

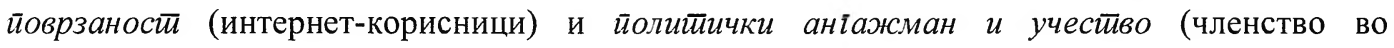
меѓународни организации, персонални и финансиски контрибути во мировни операции на ООН, меѓународни ратификувани договори и др.) (А.T.Kearney/ Foreign Policy, 2005: 56). 
Недостатоци на индексот се тие што се опфатени мал број земји и се уочува доминацијата на западноевропските земји, кои се меѓу првите десет по ранг. Воедно, не се земени предвид земјите како што е Белгија (која според другите индекси претставува најглобализирана земја во светот), исто така, не се застапени критичните земји како што се Авганистан, Ирак и други држави со цел да се избегне конекцијата на глобализацијата со тероризмот, иако постојат неаргументирани теории кои се потврдуваат со индексот на глобализираност, дека повеќе глобализираните земји се помалку ранливи на терористички напади отколку неглобализираните држави. Покрај тоа, сметаме дека авторите на овој индекс се обиделе САД, Австралија и Нов Зеланд да ги доближат до европските земји што не содејствува со реалната состојба. Слично како и претходниот индекс на глобализираност, и во овој индекс не се опфатени поголемиот дел од земјите од Западен Балкан.

За разлика од претходните индекси, индексот на Инсииийуйой за економија - KOF Index of Globalization (чии економски истражувања датираат од пред Втората светска војна) е порепрезентативен, бидејќи опфаќа 207 земји (122 земји за 2007 и 2008 година), при што се вклучени поголем број варијабли кои пообјективно и попрецизно ги рангираат земјите. Станува збор за променливи групирани во три општи категории: економска ілобализачија, сочијална ілобализачија и иолииичка ілобализачија (Dreher, 2006: 10911110; Dreher et al., 2008). На табелата што следува може да се видат кои варијабли се опфатени со индексот и колку тие се застапени. 
Табела бр. 1 - Вияови варијабли

\begin{tabular}{|c|c|c|}
\hline Категории & Варијабли & $\begin{array}{c}\text { Проценти } \\
\text { (\%) }\end{array}$ \\
\hline \multirow{10}{*}{$\begin{array}{l}\text { Економска } \\
\text { глобализација } \\
(36 \%)\end{array}$} & Актуелни текови & $\mathbf{5 0}$ \\
\hline & Трговија (\% од БДП) & 22 \\
\hline & Странски директни инвестиции (\% од БДП) & 27 \\
\hline & Портфолио инвестиции (\% од БДП) & 24 \\
\hline & Биланс плаќања на странски државјани (\% од БДП) & 27 \\
\hline & Ограничувања & 50 \\
\hline & Скриени бариери за увоз & 24 \\
\hline & Средна царинска стапка & 28 \\
\hline & Даноци на меѓународната трговија (\% од тековните приходи) & 26 \\
\hline & Ограничувања на капиталната сметка & 23 \\
\hline \multirow{14}{*}{$\begin{array}{l}\text { Социјална } \\
\text { глобализација } \\
(38 \%)\end{array}$} & Податоци за лични контакти & 33 \\
\hline & Телефонски сообраќај & 25 \\
\hline & Трансфери (\% од БДП) & 3 \\
\hline & Мегуународен туризам & 26 \\
\hline & Странски државјани (\% од вкупната популација) & 21 \\
\hline & Меѓуународни писма (по глава на жител) & 25 \\
\hline & Податоци за проток на информации & 35 \\
\hline & Интернет-корисници (на 1.000 луѓе) & 36 \\
\hline & Телевизија (на 1.000 луѓе) & 38 \\
\hline & Трговија со весници (\% од БДП) & 26 \\
\hline & Податоци за културна поврзаност & 32 \\
\hline & Број на ресторани „Мекдоналдс“ (по глава на жител) & 44 \\
\hline & Број на продавници ИКЕА (по глава на жител) & 44 \\
\hline & Трговија со книги (\% од БДП) & 11 \\
\hline \multirow{4}{*}{$\begin{array}{l}\text { Политичка } \\
\text { глобализација } \\
(26 \%)\end{array}$} & Амбасади во земјата & 25 \\
\hline & Членство во меѓународни организации & 27 \\
\hline & Учество во мисии на ООН & 22 \\
\hline & Меѓународни ратификувани договори & 26 \\
\hline
\end{tabular}

Според методолошкиот пристап на КОФ Индексот на глобализација, се следат промените на глобализацијата со помош на 23 варијабли за поголем број земји и за подолг временски период. Притоа, користени се релевантни извори на организации и институции, како што се Светска банка, Меѓуународниот монетарен фонд, Организацијата на обединетите нации, ЦИА и други. Економскийе асиекийи на ілобализаџијайа се мерат со помош на две категории. Првата категорија се актуелните економски текови, односно согледување на економската глобализација преку трговијата и странските инвестиции. Втората категорија се однесува на ограничувањата што ги преземаат земјите со цел да ја заштитат својата економија од земјите-конкуренти. Според оваа категорија, земјите кои имаат високи приходи од царини се помалку глобализирани од останатите земји. 


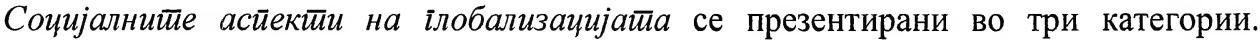
Првата ги покрива личните контакти, и се однесува на непосредните интеракции меѓу луѓето кои живеат во различни земји. Втората категорија ги опфаќа варијаблите што се однесуваат на протокот на информации и идеи. Додека третата категорија ја презентира културната глобализација која се мери според бројот на ресторани „Мекдоналдс“ и продавници ИКЕА кои за многумина се синоним за глобализација со западна проминенција.

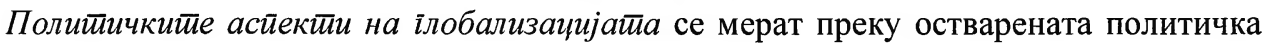
соработка помеѓу земјите. Односно, степенот на политичка глобализација се мери според бројот на акредитирани амбасади и високи претставници, членството во меѓународни организации и учество во мировни мисии на ООН, како и бројот на ратификувани договори помеѓу две или повеќе држави од 1945 година до денес (Dreher, 2006: 1091-1110).

Авторите на овој индекс на глобализираност направиле баланс помеѓу варијаблите, односно нивна еднаква застапеност. Фокусот е насочен кон економско-социјалните аспекти на глобализацијата, при што се земени предвид помал број варијабли за мерење на политичките аспекти на глобализацијата. Постојат и други пропусти, а се однесуваат на тоа дека некои индикатори (на пр. економските) се повеќе валидни од другите, што им дава предност на едни земји во однос на други. Од друга страна, недостасуваат варијаблите што ги мерат суштинските, економско-социјалните аспекти што се поврзани за сиромаштијата, нееднаквоста, социјалната инклузија, животниот стандард и други. Сепак, за разлика од останатите индекси, КОФ Индексот на глобализација дава целосна статистичка анализа за глобализираноста на земјите.

Генерално, кај сите индекси на глобализираност доминираат земјите од Западна Европа и Северна Америка кои биле и сѐ уште се најглобализираните земји во светот за периодот од 1980 до 2015 година. На самото дно, главно, се сиромашните земји лоцирани во јужната хемисфера од Земјината топка во регионите како што се Супсахарска Африка, Латинска Америка и Карибите, Средниот Исток и Северна Африка. Тоа е уште една потврда дека современата глобализација е нееднаков процес кој е претежно во корист на високоразвиените земји, додека останатите земји и региони ги заобиколува. Загрижувачки е што старо-новите предводници на глобализацијата - САД, европските лидери Франција и Германија, најразвиената азиска земја Јапонија и земјите од групата БРИКС (Бразил, Русија, Индија, Кина и Јужноафриканска Република), како и некои арапски земји (С. Арабија), се далеку од посакуваното ниво, т.е. сѐ помалку се глобализирани од некои земји кои не припаѓаат на Првиот свет. Постои сомневање во резултатите во однос на тоа како некои помали земји (на пр. за 2011 година Гватемала и Молдавија се на подобра позиција од втората економија во светот Кина или од Бразил и Индија), кои се на повисока позиција од државите кои важат за светски сили во сферата на економијата, политиката, безбедноста и технологијата.

\section{Анализа на сйейеной на ілобализираносй на земјит̆е оя Зайаgен Балкан}

Подолг временски период беше потребен земјите од Западен Балкан да се адаптираат и да се вклопат во глобалните текови. Патот што требаше овие земји да го 
поминат за нив претставуваше градење нов систем различен од веќе постоечкиот. Редицата политички, економски, воено-безбедносни и културни фактори ги одредуваа начинот и брзината на придвижување кон глобализацијата од кои зависеше идниот развој и просперитет на земјите од овој регион. До почетокот на XXI век земјите од Западен Балкан беа соочени со немили настани, почнувајќи од случувањата што доведоа до распаѓае на поранешна СФРЈ на чиј простор се водеа неколку војни, сѐ до постојаните политички притисоци, економски блокади, бегалски кризи, геноциди и конфликти, кои придонесоа овој регион да биде маргинализиран од светските случувања поврзани со глобализацијата.

Но, со постапното надминување на кризните состојби и со перманентно преземање на обврските и исполнување на должностите на меѓународен план, повеќето земји од Балканот успеаја да се вклопат првично во тековите на регионализација, а подоцна и во глобализациските процеси. Притоа, на некои земји им беше полесно да се приспособат на процесите на глобализација за разлика од некои други. Периодот на адаптирање кој требаше земјите да го поминат со цел да стекнат статус на глобализирани земји варираше од неколку години до повеќе децении. Во современата ера на глобализација тоа зависеше од можностите на земјата и од брзината на адаптирање кон новонастанатите промени.

Што се однесува на земјите од овој регион може да се забележи дека за релативно краток период од своето осамостојување успеаја да навлезат во глобализациските процеси. Напредокот на земјите во однос на глобализацијата може да се види на Табела број 2, каде што се прикажани земјите од Западен Балкан и пошироко. 
Табела бр. 2. Сйейеной на ілобализираносй на земјите оg Зайаgен Балкан за йериоя оg 2008 gо 2015 іояина

\begin{tabular}{|l|cccccccc|}
\hline \hline Земја & $\mathbf{2 0 0 8}$ & $\mathbf{2 0 0 9}$ & $\mathbf{2 0 1 0}$ & $\mathbf{2 0 1 1}$ & $\mathbf{2 0 1 2}$ & $\mathbf{2 0 1 3}$ & $\mathbf{2 0 1 4}$ & $\mathbf{2 0 1 5}$ \\
\hline \hline \multirow{2}{*}{ Хрватска } & 31 & 25 & 29 & 31 & 32 & 33 & 33 & 32 \\
БиХ & $/$ & 43 & 58 & 62 & 62 & 61 & 50 & 50 \\
Србија & $/$ & 197 & 51 & 49 & 45 & 53 & 63 & 56 \\
Црна Гора & $/$ & 190 & 198 & 46 & 43 & 45 & 49 & 48 \\
Албанија & 98 & 103 & 94 & 88 & 78 & 78 & 86 & 102 \\
Бугарија* & 44 & 39 & 32 & 32 & 38 & 40 & 39 & 31 \\
Грција* & 25 & 32 & 31 & 29 & 23 & 24 & 23 & 25 \\
Македонија & $/$ & $\mathbf{8 9}$ & $\mathbf{6 5}$ & $\mathbf{6 5}$ & $\mathbf{7 1}$ & $\mathbf{7 0}$ & $\mathbf{7 4}$ & $\mathbf{7 4}$ \\
& & & & & & & & \\
\hline \hline
\end{tabular}

* Бугарија и Грција не припаѓаат на регионот Западен Балкан.

Извор: Dreher, Axel (2006): Does Globalization Affect Growth? Evidence from a new Index of Globalization, Applied Economics 38, 10: 1091-1110; Dreher, Axel, Noel Gaston and Pim Martens (2008). Measuring Globalisation - Gauging its Consequences, New York, Springer.

Според прикажаното, најглобализирани земји од овој регион се Хрватска (Грција и Бугарија), додека најмалку глобализирани се Албанија и Република Македонија. Од земјите, најголем напредок оствариле Србија и Црна Гора, Србија од 197. место во 2009 година се искачила на 56. место во 2015 година, додека Црна Гора за периодот од 2009 до 2015 година успеала од 190. позиција да дојде на 48. позиција. И покрај тоа што овие две држави не се членки на ЕУ и на НАТО, сепак, имаат подобар рејтинг од некои земји кои се полноправни членки на овие организации. На пример, членството на Албанија и на Хрватска во НАТО (2009 година) не влијаело врз нивниот степен на глобализираност, иако многумина сметаат дека евроатлантските интеграции придонеле за побрз напредок и глобализирање на земјите. Општо земено, во изминатата деценија ниту една земја од овој регион не била меѓ 20 најдобро глобализирани земји, а ниту, пак, во категоријата на 20 најслабо глобализирани земји во светот.

Што се однесува на состојбата на Република Македонија, се констатира дека земјата имала најдобра позиција во 2010 и 2011 година (65. место), а моментално е на 74. место од вкупно 207 земји во светот. Според прикажаните политички, економски и социјални аспекти на глобализацијата, за периодот од 2009 до 2015 година, таа е најдобро рангирана според социјалните параметри на глобализацијата. Иако Република Македонија во 2015 година има најдобар рејтинг според економските параметри (57. место). Додека според политичките показатели, таа во континуитет е меѓу послабо глобализираните земји во светот (виои Табела број 3). 
Табела бр. 3 Сшиейеной на ілобализираносй на Рейублика Макеgонија за йериоg оg 2009 gо 2015 іодина

\begin{tabular}{lccccccc}
\hline & $\mathbf{2 0 0 9}$ & $\mathbf{2 0 1 0}$ & $\mathbf{2 0 1 1}$ & $\mathbf{2 0 1 2}$ & $\mathbf{2 0 1 3}$ & $\mathbf{2 0 1 4}$ & $\mathbf{2 0 1 5}$ \\
\hline $\begin{array}{l}\text { Економска } \\
\text { глобализација }\end{array}$ & 70 & 62 & 64 & 71 & 74 & 72 & 57 \\
$\begin{array}{l}\text { Социјална } \\
\text { глобализација }\end{array}$ & 49 & 52 & 53 & 55 & 53 & 62 & 67 \\
$\begin{array}{l}\text { Политичка } \\
\text { глобализација }\end{array}$ & 177 & 141 & 143 & 142 & 143 & 142 & 143
\end{tabular}

\begin{tabular}{llllllll}
\hline \hline Вкупно & 89 & 65 & 65 & 71 & 70 & 74 & 74 \\
\hline
\end{tabular}

Извор: Dreher, Axel (2006): Does Globalization Affect Growth? Evidence from a new Index of Globalization, Applied Economics 38, 10: 1091-1110; Dreher, Axel, Noel Gaston and Pim Martens (2008). Measuring Globalisation - Gauging its Consequences, New York, Springe

Меѓутоа, според одредени емпириски показатели, Република Македонија како во минатото, така и сега се наоѓa (наоѓала) меѓу високоглобализираните земји во светот. На пример, во Извешитајой на Свеиска банка (Doing Business 2008) се наведува дека земјата во категоријата спроведување на економски реформи била рангирана на 4. место во конкуренција на 175 земји. Додека во категоријата на започнување бизнис за 2015 година се наоѓа на 3. место или, општо земено, според економските показатели таа е рангирана на 30. место во конкуренција на 189 светски економии (Doing Business 2015).

Во делот на информатичка технологија, или според Извештајоти за информаиичкка теехнолоіија за 2015 година, Република Македонија е најдобро рангирана во делот на користење интернет и неговата распространетост во земјата и тоа на 47. место од вкупно 143 земји во светот. Додека според бројот на интернет-корисници, од вкупното население за 2014 година се наоѓала на 43. место (Министерство за информатичко општество и администрација на PM, 2015).

Меѓутоа, во изминатата деценија земјата најмногу е препознатлива, т.е глобализирана по учество во мисии предводени од меѓународните организации. На пример, во мисијата ИСАФ во Авганистан таа е рангирана меѓу најдобрите десет земји-членки на Алијансата. Односно, според податоците на НАТО (за придонесот на Р. Македонија за мисијата ИСАФ), таа (по глава на жител) е рангирана на 4. место и се наоѓа зад високоразвиените западни земји како што се САД, Обединетото Кралство и Данска (Министерство за одбрана на РМ, 2010).

Овие дилеми и осцилации во рејтингот покажуваат дека современите процеси на глобализација се непредвидливи и доста ризични, гледано од политички, економски и социјален аспект, а длабоко се одразуваат на севкупната општа состојба во општествата. 
Тоа значи дека за краток временски период може одредени земји од категоријата високоглобализирани земји да преминат во послабо глобализирани земји и обратно. На пример, Ирска во 2009 година била на второто место и во рок од една година (2010 година) паднала на 11. позиција. Тоа не значи дека Ирска е помалку глобализирана, туку дека другите земји многу побрзо го подобриле рејтингот на глобализираност. Исто така, Исланд, од најпосакувано место за живеење и со најдобар стандард во 2011 година, следната година (2012 година) доживеа финансиски колапс и се најде на работ на банкрот.

Едноставно кажано, за некои земји глобализирањето ќе биде тешка и сложена задача, речиси невозможна мисија, бидејќи сѐ уште некои од нив не се политички, а уште помалку економски или информатичко-технолошки созреани. Ова се однесува приближно на тоа „како да им се даде да возат болид од Формула 1 „кога до вчера јавале на магаре“ (Фридман, 2003: 382). Значи ли дека помалку способните нема да ги „вкусат плодовите“ од глобализацијата кои со децении беа собирани од страна на развиените земји? Притоа, треба да се прават разлики помеѓу силните и слабите земји кои сообразно на тоа ќе ја формулираат и својата национална економска, надворешна и безбедносно-одбранбена политика, а со тоа ќе дадат и соодветен одговор на динамиката на глобализацијата.

Во контекст на претходното, ќе ги спомнеме и случувањата на регионално и на глобално ниво што придонесоа за подобрување или влошување на степенот на глобализираност на редица земји, но и на оние од Западен Балкан, а се однесува на следново:

- проширувањето на ЕУ и на НАТО со нови земји-членки придонесе за пораст на рејтингот на глобализираност на група земји, со што се подобри нивната економска, политичка, социјална и безбедносна состојба;

- глобалната финансиска рецесија од 2008 година драстично се рефлектираше врз политичката, економската и социјалната состојба на земјите од Европа и од Северна Америка;

- настаните како што се Арапската револуција (2011 година) и кризата во Украина (2014 година) придонесоа за редица регионални промени;

- ангажираноста на земјите во меѓународните организации (СТО, ММФ, Светска банка, Г-7) и учеството во мисии предводени од ООН, НАТО и ЕУ придонесоа за зголемување на степенот на глобализираност на земјите во однос на економскополитичките и безбедносните аспекти. Притоа, високоразвиените земји, кои се и најзастапени во меѓународните организации и тела, имаат огромна предност во однос на земјите кои не се членки или се со помала одлучувачка улога во нив;

- земјите зафатени со вооружени конфликти и војни или кои се под протекторат на меѓународните организации (на пр. Косово, БиХ) имаат сѐ помалку шанси да се глобализираат, бидејќи најмалку глобализираните земји се токму оние што потекнуваат од критичните конфликтни региони (Северна Африка, Средниот и Блискиот Исток, Балканот), наспроти високоглобализираните земји кои се репер за мирот и стабилноста; 
- билатералните спорови помеѓу земјите од Западен Балкан влијаат врз евроатлантските интегративни процеси. Поради тоа, овој регион сѐ повеќе се оддалечува, т.е. маргинализира од процесите за напредок и претставува „буре барут“, опасност за регионалната стабилност (Зенделовски и Нацев, 2014: 317-318).

Емпириските резултати посочуваат и на тоа дека глобализацијата нема еднаков ефект врз многу подрачја, дејствува сосема различно и ја детерминира способноста на земјите за ангажман. Притоа се препознава односот на подреденост и надреденост, како и меѓународна поделба во однос на ангажирање на одделни институции и меѓународни организации. Некои автори се во право кога велат дека се нудат само статистички компарации меѓ општествата и врз основа на некои индикатори се подредуваат, односно тие се рангираат, без да се даде конкретно објаснување. Тоа значи дека методолошкиот пристап само квантитативно (или површно) ги анализира земјите без да навлегува во суштината на глобализацијата. Оттука, постои сомнение дека преовладува процесите на глобализацијата да се гледаат само низ индикатори и статистички анализи. Во претходно прикажаната хиерархија се подзатскриени глобалните актери - земји кои управуваат со глобализацијата и во кои владее оптимистичкото сценарио за концептот на глобализацијата, додека втората категорија ја сочинуваат земјите кои се само набљудувачи и консумери на консеквенциите од дејствувањето на глобалните актери (Ѓуровска, 2007: 83-99).

Всушност, целокупниот глобализациски дискурс се базира еднострано на демократските и економско-финансиските индикатори, додека социјално-еколошките и оние поврзани за државната благосостојба се надвор од вниманието. Тоа беше евиден̆тно и при рангирањето на земјите од Западен Балкан, кои од осамостојувањето се определија за западниот неолиберален демократски концепт. Ова посочува дека некои се повеќе вклучени во процесите за разлика од другите, а се должи на различни критериуми и географски аспекти. Доколку современата асиметрична глобализација продолжи со ова темпо, прашањето е дали поголем број од земјите во развој, вклучувајќи го и регионот на Западен Балкан, ќе успеат да се глобализираат, односно ќе го фатат „последниот воз“ што води кон просперитет и благосостојба? По сѐ изгледа, земјите на кои најмногу им треба развој ќе останат во „чекалница“, бидејќи постои веројатност глобализациските процеси да ги заобиколат, при што само мал број земји ќе успеат да се „спасат“河.

\section{Заклучок}

Постои конфузија околу тоа што претставува глобализирана земја и земјапредводник на глобализацијата. Ова се две спротивставени категории за кои нема прецизно научно објаснување. Мерењето на глобализацијата со помош на емпириски показатели е мошне сложен процес во истражувањето. Констатиравме бројни недостатоци и дилеми за тоа како функционира глобализацијата. Се забележува дека таа не е политички неутрална, ниту, пак, економски еднакво распределена, туку дека е низа на процеси што генерираат политички и економски импликации и служи во интерес на големите сили.

Земјите од Западен Балкан кои се во категоријата на мали земји во развој можат да се вклопат и да направат значителен успех во однос на глобализацијата, бидејќ е полесно 
да се управуваат за разлика од поголемите земји. Но, сепак, погрешно е размислувањето дека глобализацијата служи на помалите земји исто како и на големите земји, затоа што во континуитет расте само моќта на големите сили. Дали тоа значи дека глобализацијата е средство за манипулација (тееорија на заіовор или ияеолоіија) во полза на најразвиените земји кои придонесуваат за територијална поделба на светот по основа на капитални вредности? „Содржината на земјата“ (ресурси, популација, големина) ја одредува маркантноста на земјата на надворешен план, што има клучна улога за развојот и просперитетот. Па така, без разлика дали некоја земја е многу глобализирана или не, уште долго време големите високоразвиени земји ќе го „носат на грб“ економското, политичкото, технолошкото и безбедносното бреме. Бидејќи сѐ се сведува на поинакви мерила кога е во прашање големината (обемот) на производство на добра и услуги и големината на пазарот (колку што е поголем пазарот, толку е поголемо производството, а тоа резултира со поевтина стока и услуги), географската големина, местоположбата во хиерархијата на држави, ресурсите со кои располага, интегрираноста во светските економски текови, вклученоста во регионални и меѓународни организации, технолошкиот напредок и иновации. 


\section{Литеерайура}

Bagvati, J. (2008). U odbranu globalizacije, Sluzbeni glasnik, Beograd.

Center for Study of Globalization and Regionalization, Newsletter, issue 16, december 2006.

Doing Business 2015: Going beyond Efficiency, The International Bank for Reconstruction and

Development, The World Bank, Washington DC, (достапно на: http:/www.doing business.org/data/exploreeconomies/macedonia-fyr).

Dreher, Axel (2006): Does Globalization Affect Growth? Evidence from a new Index of Globalization, Applied Economics 38, 10: 1091-1110.

Dreher, Axel, Noel Gaston and Pim Martens (2008). Measuring Globalisation - Gauging its Consequences, New York, Springer.

Фридман, Т. (2003). Лексусой и маслиновойо орво, Тера магика, Скопје.

Globalization and Future Architectures: Mapping the Global Future 2000 Project, Report of a Conference on June, 2005, Chatham House, London.

Гууровска, М. (2007): „Соџиолошкийе асиеекӣи на ілобализачијайа“, Годишен зборник 60, Филозофски факултет, Скопје: 83-99.

Kearney A.T., Measuring Globalization, Foreign Policy, January-February 2001, JanuaryFebruary 2003, March -April 2004, May-June 2005, November-December 2006,

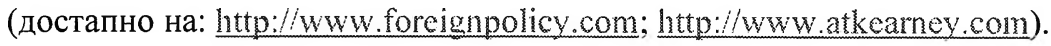

KOF Index of Globalization,(достапно на: http//globalization.kof.ethz.ch/).

Lockwood, B. \& Redoano, M. (2006): The CSGR Globalization Index : an Introductory Guide,Center for Study of Globalization and Regionalization, Newsletter, Working Paper 155/04, issue 16 (достапно на: http://www.2warwich.ac.uk/fac/soc/csgr/index/).

„Макеоонија найреяува за 10 йозииии на свейскайа информайичка майа“, Министерство за информатичко општество и администрација (достапно на: http:/ www.mio.gov.mk/? q=node/3945) April 2015.

Мекгру, Е. (2009): „Глобализачијайа и светискайа йолийика“, во: Глобализацијата на светската политика, Вовед во меѓународните односи,Табернакул.

Недялкова, А., Бауман, 3. и Филипов, Д. (2005). Глобализъм, Реіионализъм и Анйиілобализъ.м, Албатрос, София.

Pavlovic, V. (2009). Drustveni pokreti i promene, Sluzbeni glasnik i Zavod za udzbenike, Beograd.

„Прияонесой на Рейублика Макеяонија кон ілобалнайа безбеяносй, мир и сииабилносии“, Министерство за одбрана на РМ, април 2010, (достапно на:

http:/www.morm.gov.mk/wp-content/uploads/Pridones RMakedoniia MAK apr 2010.pdf).

Reinert, E.S.(2006). Globalna Ekonomija: Kako su bogati postali bogati i zasto siromasni postaju siromasniji, Cigoja stampa, Beograd.

Solte, A.J. (2009). Globalizacija :kriticki uvod, (drugo izdanje), CID, Podgorica.

Steger, M.B. (2005). Globalizacija, Sahinpasic, Sarajevo.

Зенделовски, Г. и Нацев, 3. (2014). Глобализачија, мирой и безбеоносита, Филозофски факултет, Скопје. 


\section{THE DEGREE OF GLOBALIZATION OF THE WESTERN BALKAN COUNTRIES}

\section{Summary}

Globalization does not equally impact on countries act in different countries with different levels of political, economic and technological development. Its unequal distribution across regions, countries or communities confirms that it is a complex and deep asymmetric process. It was confirmed by numerous theories and debates only to explain and define the phenomenon, but little attention paid to the complexities of globalization and measuring its range. With the help of empirical variables and indicators can measure the differences between national and international in different domains. In that way it allows to be seen to what extent countries are globalized, or be perceived strong influence on globalization processes on the overall situation in societies. Therefore, a larger number of countries are trying to take advantage of the processes of globalization to promote the national interests and the improvement of its position in international relations. Hence the analysis of the indexes of globalization will help us to comprehend with which components of national power countries dominate on the regional and global scene.

Keywords: INDEXES OF GLOBALIZATION, VARIABLES, RATING, WESTERN BALKAN 